\title{
Courts and (epistemic) communities in the convergence of competition policies
}

\author{
Frans van Waarden and Michaela Drahos
}

\begin{abstract}
How much did national competition policies converge between 1950 and 2000, and what were the forces behind this? These are the questions the paper attempts to answer, for three countries whose competition policies differed substantially at the outset: Germany, Austria and the Netherlands. The paper measures the degree of convergence of national competition policies, and concludes that there has been convergence towards the stricter EU anti-trust norms. This can be explained by neither negative ('the market') nor positive ('the state') integration, as competition policy is one of the few policy areas where the EU has never explicitly tried to harmonize national legislation.

Other forces must have been at work. We investigate the role of various actors, which each play a role in three theories of European integration: institutionalism, which stresses the importance of the central European institutions; neofunctionalism, which focuses on international business; and the epistemic community approach, which highlights the importance of transnational expert communities. We find that convergence has been mainly the work of subtle 'topdown' pressure from the CEC and the ECJ ('the courts'), combined with the emergence of an epistemic 'community' of legally trained officials, which has been a channel for the exchange of information, ideas, solutions and arguments between the systems and levels of law. EU case law provided an important model, experiment and source of norms for this community.
\end{abstract}

KEY WORDS Case law; competition policy; convergence; epistemic communities; institutionalism; soft harmonization.

\section{INTRODUCTION}

The two classic channels for convergence of national regulations in the European Union (EU) are: a) 'the market', i.e. regulatory competition under the rule of 'mutual recognition', leading to what has been called 'negative harmonization'; and b) 'the state', the European state authorities (Council, Commission, Parliament), which 'impose' regulations and directives upon the member states, i.e. 'positive harmonization' (Scharpf 1996). This paper focuses on a policy field where neither positive nor negative harmonization of national 
regulations has taken place: competition policy. Although the European Commission has enacted many regulations and directives to harmonize national regulations, it has, remarkably enough, never done so in one of its oldest policy fields, that of competition policy. Even though the Union has its own competition rules for inter-state trade, member states also have their own competition regulations, and these used to differ substantially. These differences have, however, never led the Commission to explicitly try to harmonize these regulations. We will investigate a) whether there has been some convergence even in this case - and will attempt to 'measure' policy convergence; and b) what the channels for European influence on such 'soft harmonization' may have been. In particular, we will look at the role of the producers of European case law, the Commission and the European Court, and the role of an epistemic community that has emerged around this growing body of law. Can it be that national governments have adjusted their policies in some direct or less direct response to case decisions of the Commission and the European Court?

In section 2 we try to measure any convergence in the national competition policies of Germany, Austria and the Netherlands, also seen in relation to EU competition norms. Section 3 addresses the question of what the driving forces behind convergence may have been in this case. We do so by investigating the possible role of various actors and institutions, as suggested by different theoretical approaches to European integration: institutionalism (major role for central European institutions), neo-functionalism (international business as driving force), and the epistemic community approach (role for a transnational expert community). We conclude that in this case convergence has been the result of the gradual and largely implicit pressure and possibilities for mutual modelling arising from the development of a multi-level split legal system, mostly in the form of case law, which, however, has been channelled between the levels through the lines of communication and exchange created by the development of a multi-level epistemic community of legally trained officials; i.e. a combined effect of institutionalism and the epistemic community approach.

\section{CONVERGENCE OF NATIONAL COMPETITION REGULATIONS: AUSTRIA, GERMANY, THE NETHERLANDS}

The member states' competition policies differed substantially. Nevertheless, and unlike other policy fields, the Commission has never explicitly tried to invalidate them or force national governments to change their competition laws and bring them in line with common EU standards. Rather, it was satisfied with superimposing European rules on those agreements and practices that have an effect on trade between member states.

While there has been no 'positive harmonization', there has been no 'negative harmonization' either. Regulatory competition would have been possible only to some degree: competition policy affects not only firms that 
produce in a country but also undertakings that merely sell in a country. The only possibility for an enterprise which wants to avoid the cartel rules of, say, Germany is not to do any business in Germany at all. Furthermore, while regulatory competition is usually associated with a race to the bottom towards fewer or more market-friendly regulations, one would expect the opposite in competition policy. Countries competing for firms and employment would have done so by offering more rather than fewer possibilities for collusion, resulting in a convergence of national laws on less strict standards, but in this case that meant fewer pro-market regulations. This does not seem to have happened.

Notwithstanding the absence of positive harmonization, some convergence has taken place. And indeed, it has been mostly a convergence towards the EU norms, not away from them, as would have been expected from negative harmonization, as argued.

Originally the difference with the EU's strict anti-trust policy was quite large because of the long-standing cartel-friendly tradition in many member states. The policies of the various member states also differed a great deal from one another. In this study we investigate the differences in competition regulation in three member states, Germany, Austria and the Netherlands, in relation to the regulations of the EU. We chose these countries because they opted for fundamentally different material and institutional rules after the Second World War. They also showed different modes of adaptation and have moved in different directions even in the recent years of harmonization. These three countries, therefore, represent a large part of the diversity of competition policy developments in Europe. They include the extreme case of the former cartel paradise and now ardent adapter, the Netherlands, the adaptation laggard' Austria, and the former best pupil in the class and now somewhat resistant Germany.

We have focused on two periods, 1950 and July 2000, allowing us to make not only a comparison between the countries, but also a comparison over a relatively long period within each country. The comparison over time has enabled us to determine whether the competition policies in each of these countries have converged: have they moved towards each other and towards the EU norms? Or have they remained different, casu quo even diverged?

We have compared their regulatory systems on seven main dimensions:

1 Goals and basic principles: for example, is competition a goal in itself or is it formally seen as a means to further goals?

2 Application: what organizational arrangements are in place for the application of the law?

3 Scope: how broad is the scope of the law? Does it pertain also to, for example, the liberal professions or (semi-) public organizations? Are sector exemptions included or easily given?

4 The treatment of horizontal restraints of trade, the classic 'hard' cartels. 
5 The treatment of vertical agreements, such as resale price maintenance or exclusive distribution or licensing agreements.

6 The regulation of abuse of a dominant market position.

7 Merger control.

For each of these we have distinguished a number of sub-dimensions.

In Table 1 we have tried to summarize and 'measure' the degree of convergence of competition regulations in the three countries in relation to EU norms. As a point of reference we have taken the position of EU competition law in mid-2000. The EU position itself, of course, also moved between 1958 (when it was originally formulated) and 2000 - in that sense it is a moving point of reference. The most important changes have been the introduction of merger control, the on-going codification of exemptions, the drafting of numerous guidelines, and - above all in recent years - a shift from a more legalistic approach towards an emphasis on problems of market power. The movement of EU law has been relatively limited in the sense that the basic rules in the Treaty have remained the same. In order not to complicate the comparison too much, we have therefore taken the 2000 position as our point of comparison for national regulations. We have done so for the beginning and end of the fifty-year period: how different were the 1950 competition regulations in member state A from the EU regulations in 2000; and how different were the member state regulations in 2000 from the 2000 EU regulations? The comparison between both scores enables us to estimate the degree of convergence in reference to the EU norms. Scores have been given on a sevenpoint scale. ' 0 ' means that the member state regulations were more or less similar to those of the EU. A negative score $(-1,-2,-3)$ indicates that they differed in the sense of being more strictly anti-trust; a positive score $(1,2,3)$ indicates a difference of being more lenient towards cartels and monopolies. An ' $\mathrm{x}$ ' has been given when the issue was not covered in the member state regulations at that time. We will now discuss the most important aspects of the various main dimensions of comparison. For a comparison of all sub-dimensions, see Table 1 and Drahos (2001). In the limited space available in this article we cannot deal extensively with the original positions of these countries, their theoretical and ideological backgrounds, and the detailed changes in these systems over time. A more detailed description can be found in Drahos (2001).

\subsection{Goals}

Under the main dimension 'goals' we have distinguished four variables.

First, the basic principle underlying the law. Is it an abuse regime, under which restraints of trade are in principle acceptable, unless they can be argued to be detrimental to the common good? Or is it a prohibition regime, where the opposite holds, where the burden of proof is on those who want to practise restraints of trade? 
In the 1950s there were important differences in the attitude towards horizontal agreements. Only the EU and Germany had a prohibition regime at that time. Austria and the Netherlands merely had abuse control. In 1998 Holland changed over to a prohibition regime. This gives the Netherlands a score of '2' on convergence between 1950 and 2000. Austrian law is still based on the abuse principle. Unlike the old Dutch regime, it is an ex ante-abuse control, though. Inter-firm agreements have to be registered, which can be refused if they are considered to lead to abuse.

The second variable is the definition of competition. Is absolute or 'complete competition' the goal, or is a more pragmatic conception, 'workable competition', the aim? The EU rules now officially pursue 'workable competition'. In practice, this has been the aim of EU policy since the outset, but it has been made more explicit. Implicit use also characterized Austria and the Netherlands around 1950. Now the Dutch have copied the 'workable' definition from the EU. Austrian law is still vague on this issue.

The third issue is whether competition is seen as an end in itself, or whether it is considered a means to other economic ends, such as low inflation or high innovation. The latter implies that, if these other ends can under certain circumstances be better reached by a certain mitigation of competition, this would be legitimate. European law accepts this idea. The three national regimes have moved towards this European stance, albeit from different positions.

An even greater qualification of competition is if restraints of trade are also acceptable for non-economic reasons, such as environmental or cultural ends (e.g. resale price maintenance for books). EU case law has not incorporated such goals in the general exemptions. However, the Treaty now stipulates that concerns about the environment, culture, consumer protection and public health have to be integrated into EU policies. This also applies to competition policy. Such an inclusion of more general objectives has been difficult in Germany. The Austrian and Dutch regimes formerly allowed for this, but both have restricted the possibilities.

\subsection{Application}

The second cluster of variables pertains to the enforcement of cartel law, and the nature of the agencies and actors involved.

Most important is the nature of the competition authority. All systems, except the Austrian, have concentrated the tasks of investigation, decisionmaking and sanctions within one authority. They differ, however, in the degree of autonomy from political influences. The EU has no such independent authority. All cases and most secondary legislation are prepared by DirectorateGeneral (DG) Competition, and decisions are taken by the Commission of the European Communities (CEC), which allows for influence from other DGs. By contrast, Germany and Holland have independent competition authorities, the Bundeskartellamt and the Nederlandse Mededingingsautoriteit (NMa), 


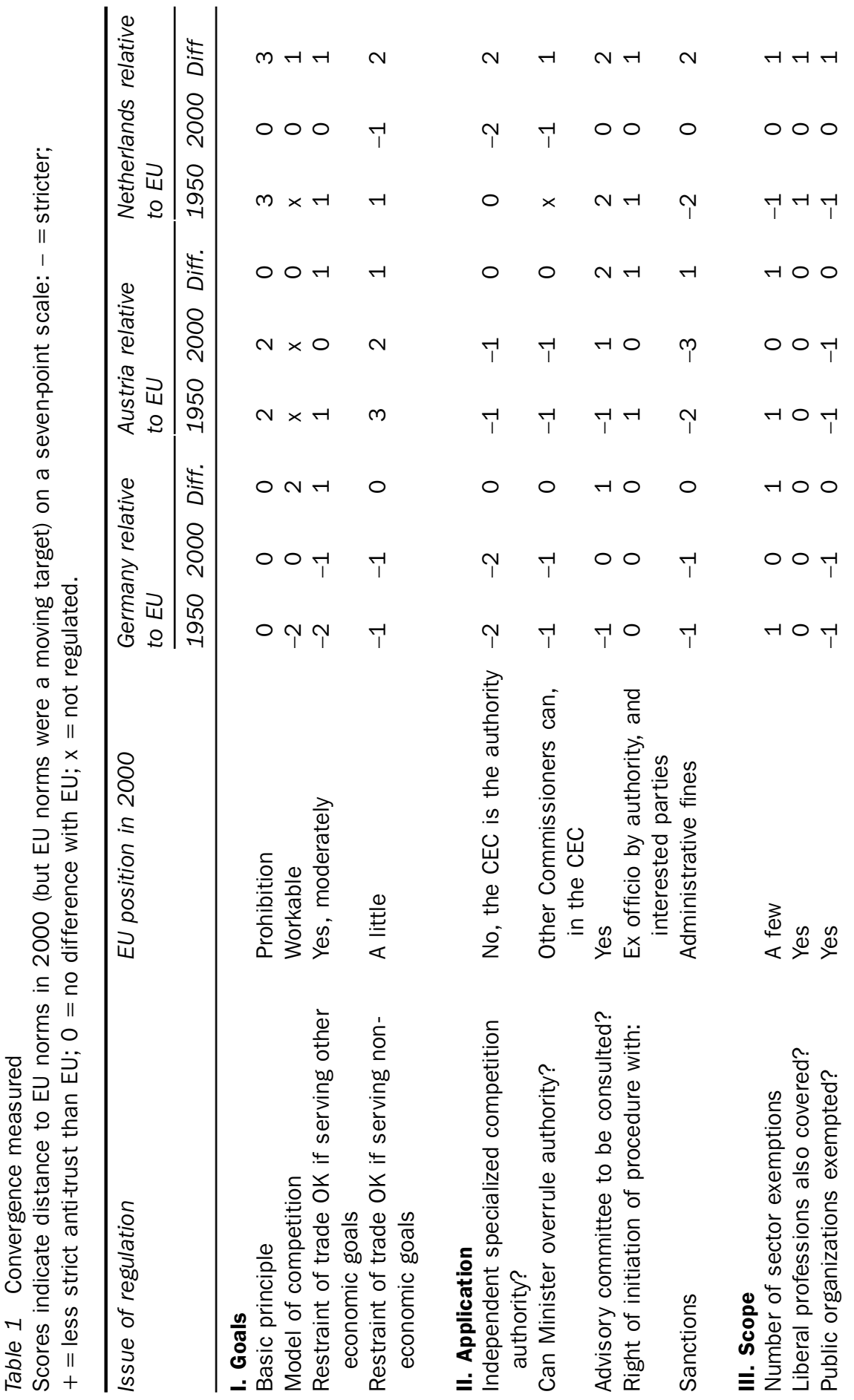


F. van Waarden \& M. Drahos: Courts and (epistemic) communities

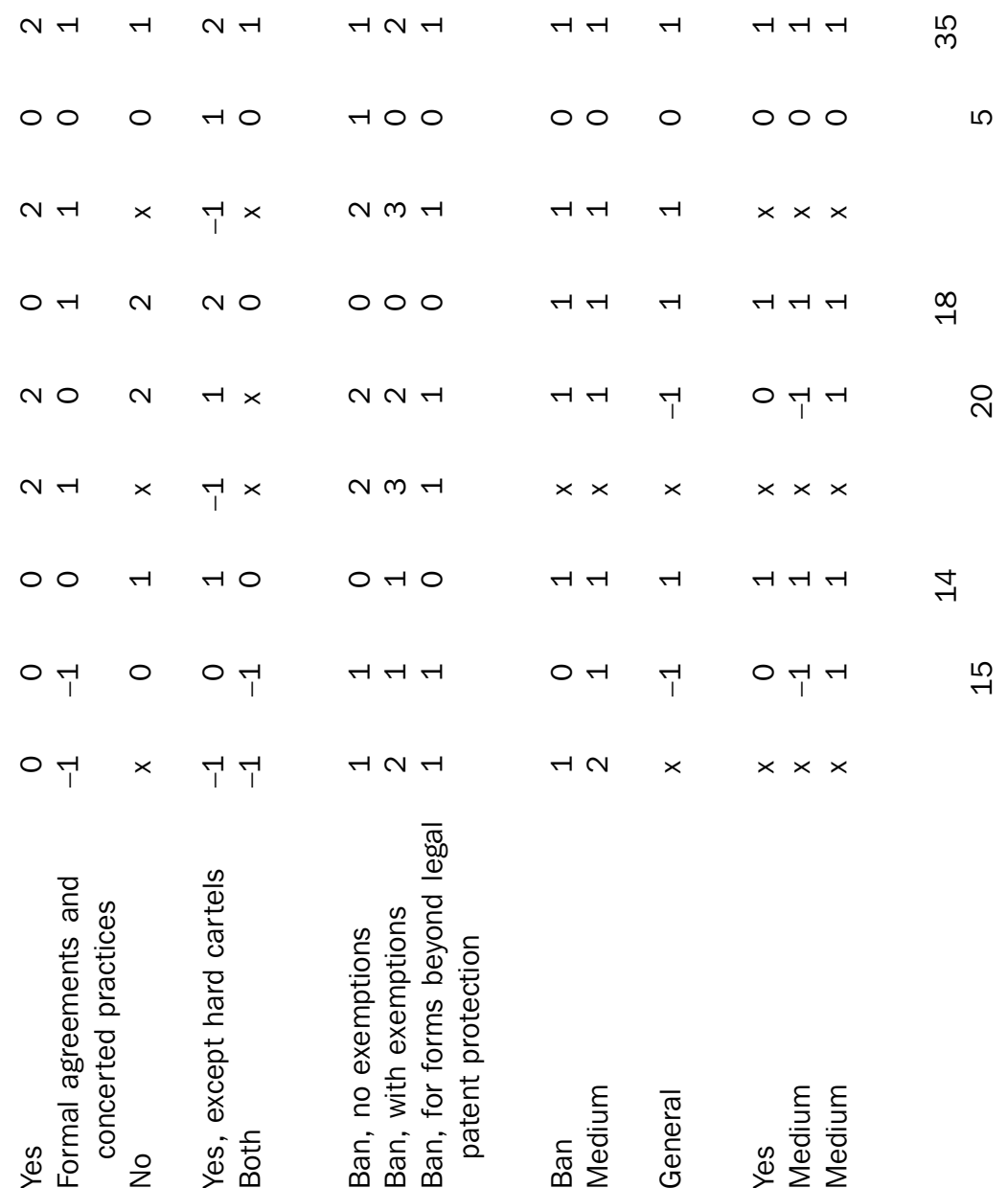

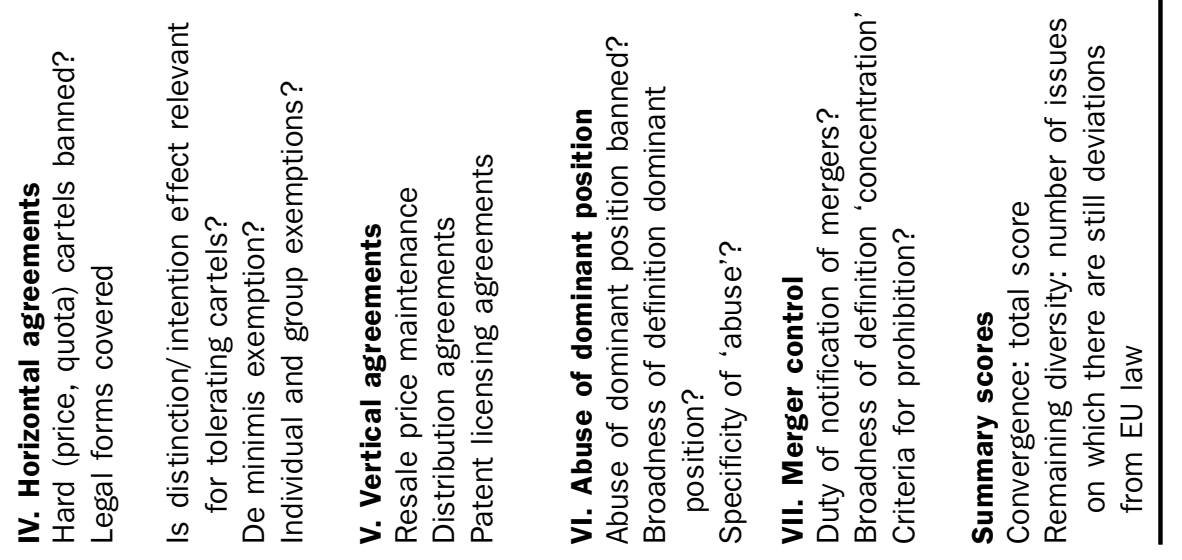


placed at arm's length from the government. The Germans have had this agency since the 1950s; the Dutch only created it in 1998. Previously, the Dutch law was applied by the Ministry of Economics. In Austria, the Competition Act is still applied by the cartel panel of a civil court ('Cartel Court'). Final enforcement is carried out by the criminal courts. This should ensure independence from politics. However, this is mitigated by the fact that the initiating investigation is done by an advisory body formed by the social partners (who also appoint lay judges in the Cartel Court). ${ }^{1}$

The agencies' autonomy can be limited by the power of the Minister to overrule agency decisions. In the CEC the Commission takes the decision. The German and Dutch Ministers of Economics can overrule their agencies in some cases. In Austria the Cartel Court resides under the Justice Minister. However, as it is a court, the Minister cannot give instructions.

As regards the nature of sanctions: in the 1950s the systems could be lumped into two categories. The European and German systems have had administrative fines from the beginning. The Austrian and Dutch systems provided for criminal sanctions, including imprisonment. Those sanctions were, however, hardly ever imposed. The Dutch system has now taken over the European system of administrative sanctions; Austria has retained criminal law enforcement.

\subsection{Scope}

The impact of cartel law is also determined by its scope: to how many segments of the economy does it apply? Does it also concern less obvious sectors, such as the liberal professions or (semi-) public organizations? And how easily are sector exemptions given? And how many are given?

In all systems one can perceive a widening of the scope of competition law. Sector exemptions have been reduced in the EU, Austria and Germany (where they mitigated the strictness of the law), while the Dutch have introduced some under the new (more restrictive) law. They also extended the scope to the liberal professions, which was already the case in the other systems.

\subsection{Horizontal agreements}

The EU, German and Dutch systems prohibit horizontal agreements on prices, quotas, market-sharing, etc. For the Dutch this is new. The Austrian default rule is still 'permission after registration'.

The systems differ in the legal forms covered. All apply to agreements (including gentlemen's agreements), concerted practices, and the decisions of business associations. This is new to Austrian and Dutch law, which formerly pertained only to explicit formal contracts.

For EU, German and Dutch law the distinction between intention and effect is irrelevant. (In the past intention was decisive.) They prohibit agreements that are 'aimed at' or have 'the effect of' restricting competition. Under 
the Austrian ex-ante abuse regime, only agreements with the intent to restrict competition have to be registered, and this can be refused.

All four systems apply only to agreements that restrict competition to an appreciable extent ('de minimis' exemption), a parallel development in all systems. An important difference is that the EU and Germany exclude the 'hard' cartels from the 'de minimis' benefits. This is not the case in the Netherlands and Austria.

\subsection{Vertical agreements}

Resale price maintenance is a major 'sin' and therefore prohibited under European, German and Dutch rules. This was already the case in Europe and Germany. In Austria, resale price maintenance is subject to the same rules as horizontal agreements. They have to be registered.

The first three systems allow for some group exemptions, notably for banks and insurers (Germany), newspapers and retail (the Netherlands), and books (all three countries). Under EU law exemptions have little chance, but the Commission is lenient regarding collective resale price maintenance for books, as long as they are not transnational.

As regards the granting of territorial protection to distributors, the EU has recently adopted the more lenient approach which some member states used to have. This meant that the Netherlands, which adopted the EU approach in 1998 , ended up with a more stringent system than the EU (duty of notification). The difference would be more important if Dutch law did not provide for an automatic incorporation of all European block exemptions. The EU and the Netherlands have a group exemption for vertical distribution contracts or franchising, between firms with less than 30 per cent market share and without 'black' clauses like price agreements or absolute territorial protection. In Germany and Austria, distribution contracts are subject to abuse control only, except that in Germany prohibitions of unfair hindrance and discrimination also apply to vertical agreements.

Patent or know-how licensing agreements are only forbidden in the four systems if they go beyond the protection granted by intellectual property rights law. They differ, however, concerning which restraints the law considers go beyond this threshold.

\subsection{Abuse of dominant position by powerful firms}

The EU has prohibited the abuse of a dominant position from the very beginning. German and Dutch law was less restrictive, only allowing for intervention if necessary, not outright prohibition. Austria had no rules on the matter. There has been some convergence, as now three systems, the European, German and Dutch, prohibit the abuse of a dominant position, whereas Austrian law has introduced the possibility of intervention. 
The systems differ in the definition of a 'dominant position'. The EU (followed by the Netherlands) formulates it as an economic position which allows a firm to 'prevent' effective competition. Germany originally had a more restrictive conception: the actual absence of a competitor. Now Germany has a broader definition than Europe, through stricter quantitative criteria and special rules for firms with a strong market position vis-à-vis competitors or buyers. This broadening of the norms was a reaction to the demands of small and medium-sized enterprises for protection. Austria combines European and German notions, which also results in a stricter definition than the Dutch and European one.

Systems differ in what constitutes 'abuse'. European and Dutch law contains merely a general clause, and European law gives some examples, such as unfair prices, limitation of production, markets or development, and tie-in. German and Austrian law gives some additional examples, such as the refusal to grant access to essential facilities (German) and selling below the purchase price.

\subsection{Merger control}

There has been some parallel change as all four systems have introduced the duty to notify the authorities about mergers, something which was absent in 1950. However, they differ slightly in the broadness of the definition of 'concentration' (and hence in the scope of the regulation), as well as in the criteria for prohibiting a merger. Germany and Austria maintain a somewhat broader definition of 'concentration', implying that the law has a broader scope of application. They are, however, less strict in the criteria for prohibition. In Germany and the Netherlands, the Minister of Economic Affairs may grant special permission for reasons of public interest for a merger that has been prohibited by the cartel authority.

\subsection{Summary scores}

In Table 1 we have scored the three national systems in 1950 and 2000 compared to the position of EU law in 2000, and 'calculated' a number for the change in each system in between these two years on the variables just discussed. At the foot of the table we have added the scores for change towards the EU norm. These are only rough approximations, but help in reducing complexity and indicate the dominant tendency.

The overall score of 'convergence' for the Netherlands is 35, for Austria 18, and for Germany 14. This confirms our general impression that the Netherlands, whose system was originally the most different from EU law, has changed most in its competition law. The system which was originally closest to EU law, the German prohibition system, has changed least. This confirms the theory of Héritier (1995), Héritier and Knill (2000), and others, who have stated that the pressures for convergence will be greatest where the original distance between national and EU policies has been the greatest. 
The table also allows us to calculate the number of variables on which the national competition regulations still differ from the EU in 2000 , i.e. the cases where there is no ' 0 ' in the country positions for 2000 . Here the Netherlands scores the lowest, with only five items still being different. This was to be expected, as the Dutch oriented themselves very strongly on EU law when overturning their legislation in 1998. Germany, notwithstanding its original closeness to EU law, still has some differences, on fifteen out of twenty-six items. Austria is still the furthest from EU law, with twenty items being different. Notably, its system of application and enforcement is different, and this has consequences for other items.

\section{CAUSES OF CONVERGENCE}

The degree of convergence between national competition policies is striking, considering the fact that the forces for positive and negative integration have been absent. Is this a case of what has been called 'spontaneous' harmonization? And if so, what is that? Some deus ex machina? Why should national actors work 'spontaneously' in the same direction for convergence? If something like that works, through which processes and channels does it do so? Could it be that such spontaneous harmonization was influenced by EU law in more subtle, softer ways than through positive or negative harmonization? The fact that convergence went towards the EU standards seems to suggest this. Let us look at some possible channels and influential actors. Subsequently, we will discuss the role of various European actors and institutions, which are given a central position in different theoretical approaches to European integration: a) institutionalism, emphasizing the role of central European institutions; b) neo-functionalism, perceiving integration as the result of pressure from international business; and c) the epistemic community approach, highlighting the importance of transnational expert communities.

\subsection{Institutionalism: pressure from the central European institutions}

The institutionalist approach in the European integration literature emphasizes the leading role of the European institutions, notably the Commission and the European Court of Justice (ECJ), as well as their product, the growing European legal system, in the process of European integration. To what extent can this force explain the gradual harmonization of national competition laws?

Authors writing on the convergence of European national competition acts do indeed refer to the European Community as the important driving force (Laudati 1998; Dumez and Jeunemaitre 1996; Gerber 1998). Gerber argues that EU competition law put pressure on the member states to align their legislation with that of the EU, so that some countries introduced cartel law for the first time and others tightened an existing Act. Dumez and Jeunemaitre write that it was the 'objective of European competition policy to harmonize 
competition', and that 'this competition policy, enforced centrally from Brussels and implemented in the individual member nations, led to vertical convergence, voluntarily accepted and enforced under law' (1996: 228-9).

We disagree with this simple argument. The authors do not demonstrate how any such pressures might have been exerted. As we have already indicated, it cannot have been through explicit harmonization of national competition laws, as the CEC never attempted this. Perhaps there were other forms of 'topdown' pressure from European institutions but, if so, what and how precisely? Was there any role for European rules and European case law? Did they put any formal constraints on national governments?

The European institutions first generate abstract regulations, codified law. In competition policy this has, however, remained limited. It consists mainly of Articles 81, 82 and 86 of the Treaty of Rome. These have a direct effect, i.e. they are aimed directly at enterprises and - except for Article 86 - not at national legislation. The Articles do not have to be transposed in national law. The existence of some basic rules with direct effect withdrew the legal basis for harmonization in the view of the CEC. Harmonization of national legislation was only legitimate in so far as it hindered the functioning of the common market (old art. $100 \mathrm{EC}$, as amended art. $94 \mathrm{EC}$ ). National cartels were not supposed to, and were therefore a purely national matter. Thus two systems of competition law evolved parallel to one another: a national one, and a European one.

European institutions, such as the Commission and the ECJ, also produce, however, law in the form of individual Decisions - a body of rules which we will group together under the term case law. Given the scant codification, EU competition law has mostly developed in the form of such case law. Has there been any influence of such European case law on national competition law?

Case law created first some basic principles, which set limits to national options. Walt Wilhelm established the principle of the supremacy of European law in the case of competition policy. The Court ruled that national law could be applied parallel to EU law, but that national competition regulations could not be in conflict with European law in those areas where the latter applied.

This requirement became more important with the extension of the jurisdiction of EU law owing to the increase in intra-EU trade and the related blurring of the boundaries of national markets. This meant that EU competition law was also increasingly applied to what were formerly considered purely 'national' cartels on national markets, if only because national markets should be open to entrants from abroad.

However, the practical effect of the principle is weakened by the unclear delineation of jurisdictions as regards restrictive agreements and dominant positions. Only in merger control do quantitative thresholds demarcate the boundaries between national and European jurisdiction. Furthermore, the ECJ rule that national legislation may not obstruct EU law has never really been tested. No ECJ judgment has dealt directly with a national competition act. 
Influence is exerted largely through individual decisions. The principle implies merely that national competition authorities may not take decisions that deviate from a CEC decision in the same case.

In addition, only rarely has the CEC tried to influence national competition law directly with case decisions. A rare attempt was the CEC decision to prohibit and fine the Dutch construction cartel, which was not prohibited under Dutch competition law at the time. The CEC argued that firms could interpret this non-prohibition as confirmation of the legality of their conduct. Dutch secondary legislation would thereby obstruct the proper working of EU law. It therefore commenced an infringement procedure before the ECJ. As the Dutch government amended its competition law on this point, the CEC refrained from continuing the procedure, so that we do not know how the ECJ would have decided.

More frequent were instances of case law which put only indirect and implicit pressure on national competition law by banning cartels hitherto accepted by national competition authorities. An overruling Decision of the CEC did not rule directly against national law; it ruled against its consequences. The CEC has done so frequently.

Table 2 shows the distribution of CEC decisions by the member state in which the main firm or association was located. Among the three countries studied in this paper, the Netherlands has the highest number of cases related to its share in intra-EU trade, and Austria the lowest. The same order holds for the percentage of these cases which concerned 'national agreements' - the Netherlands 23 per cent, Germany 8 per cent, Austria 0 per cent - and for the percentage of those in which the CEC intervened with a negative decision the Netherlands 75 per cent, Germany 42 per cent, Austria 0 per cent. In Austria the CEC had not yet 'tackled' any national cartels, probably because of its recent membership. This indicates that, as regards our countries, the pressure from 'overruling' was strongest in the Netherlands, less so in Germany, and non-existent in Austria.

Obviously, national authorities perceived such CEC Decisions as implicit criticism and as a threat to their autonomy. Their reaction was an inclination to adapt national law to European law. The German Ministry of Economic Affairs suggested in early drafts of the last amendment of the German cartel law Gesetz gegen Weltsbewerbsbeschraenkungen (GWB) that the autonomy problem might be lessened by adaptation. Applying the same law might even give the Bundeskartellamt a more important role in developing European competition policy. The Dutch Ministry of Economic Affairs hoped that convergence would lead to less supervision by the CEC and more influence in important national cases, e.g. through the referral of mergers. The CEC also signalled that adaptation would indeed be rewarded with a greater role and autonomy for national authorities. The importance of this implicit EU institutional pressure is underscored by the fact that the country which was least 'overruled', Austria (because of its later entry into the Union), has converged the least with the EU competition standards. 
926 Journal of European Public Policy

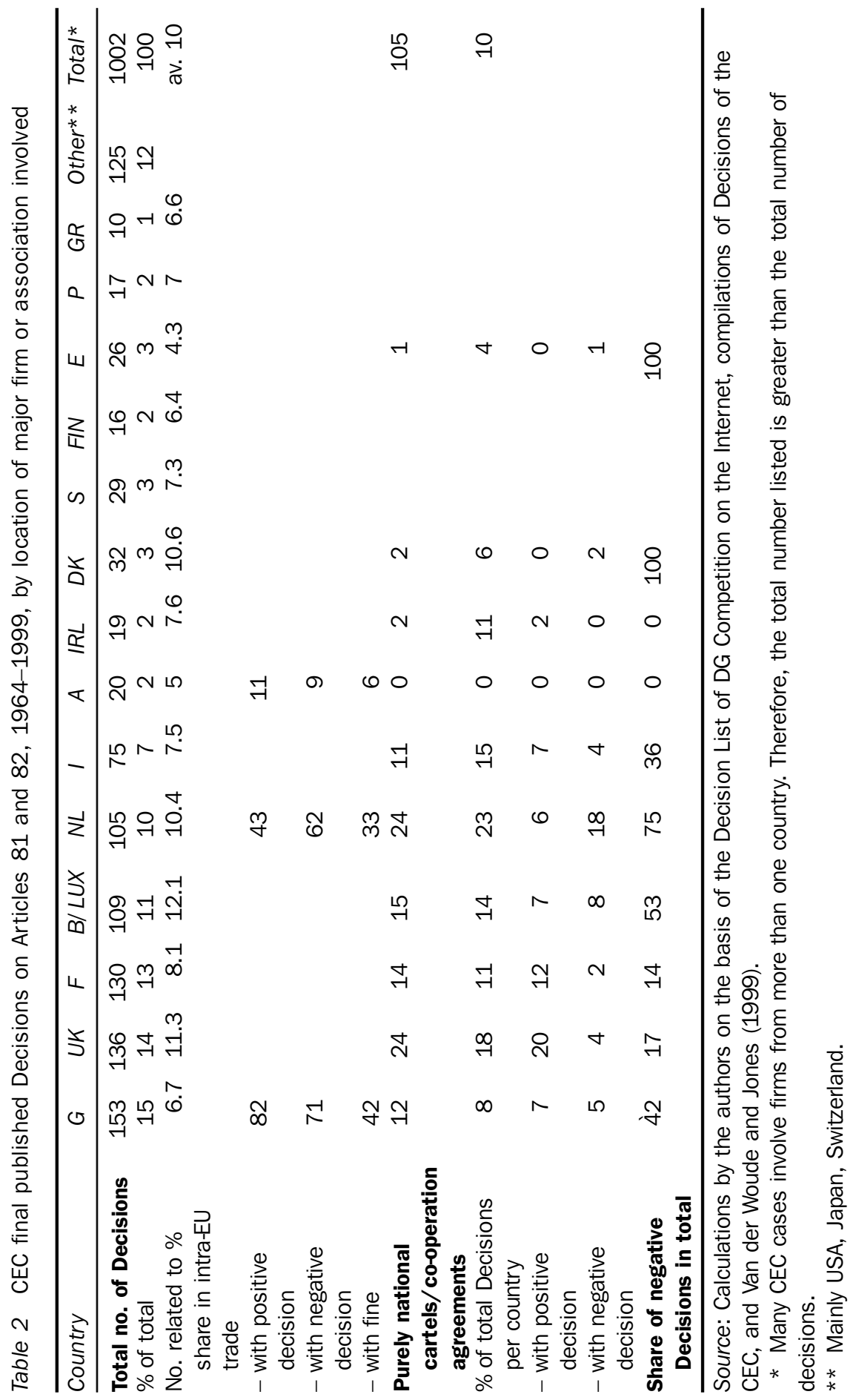


Once again it should be stressed that member states have not been forced directly to harmonize their national competition legislation. Were mere differences in judgments and indirect criticism enough to bring about convergence? Why should national policy-makers be concerned about this? What other forces are at play? Is there a role for external pressures here, e.g. from business or politics? Or are there perhaps still other channels which help in making such criticism an effective force for change?

\subsection{Neo-functionalism: economic interests?}

A major driving force for convergence, suggested by earlier neo-functionalist theory, was pressure by economic interest groups (Haas 1964; Lindberg and Scheingold 1971). Neo-functionalist theory assumed that European integration was driven primarily by business interests, rather than by political or administrative actors; and that first steps towards integration, initiated or brought about by these economic interests - in the first place the creation of a common market - had spill-over effects in other policy areas, which were in turn again supported by economic interests. Can this neo-functionalist theory explain convergence of competition policies?

There are various reasons why one might expect such pressure. The existence of two, more or less overlapping and competing, legal systems in itself creates an agenda problem for policy-makers, but especially for industry which has to contend with both. The double system would in theory raise costs for business. Different competition laws mean double notification costs and the need to adapt international transactions to contradictory provisions. In addition, it brings uncertainty over which practices are allowed and which are not, and this uncertainty is translated into costs, e.g. those of obtaining legal counsel. Reason enough for business to exert pressure to reduce the diversity of legal norms.

Our study, however, indicates that business lobbies did not carry sufficient weight for change, for various reasons. First, the former Austrian and Dutch laws were hardly enforced. Therefore, the costs imposed by these laws were in any event low, so adaptation would not have brought a significant decrease in the administrative burden. But once it became clear that the Dutch government was intent on introducing the prohibition principle and on more active enforcement, business preferred adaptation to EU law.

Given the laxity of Austrian and Dutch law, most cases of explicit pressure from business for harmonization were to be found in Germany. But here too the pressure was limited. Firms doing business on an international basis only demanded adaptation when European law was more lenient. The peak industrial association Bundesverband der Deutschen Industrie (BDI) only favoured adaptation to European regulations regarding horizontal agreements, not vertical ones (the latter also because Europe was adapting to German standards, and these were considered superior). The few explicit lobby attempts at adaptation to Europe which were made, failed. 
The main reason for weak business pressure for convergence was that business was usually split on the issue of competition policy. A clear-cut case where internal division weakened the position of business interests was in the German debate about reducing sector exemptions: while other industrial interests favoured this, the sectors concerned resisted strongly. Another example concerns the rules on dominant firms in Germany. Those norms, unfavourable to larger firms, were in part broadened at the instigation of small firms.

\subsection{The epistemic community approach: exchange, communication, borrowing, modelling}

\subsubsection{Competition lawyers as an epistemic community}

The most important channel for the influence of EU competition law on national competition law was probably not economic or political interests but an expert community, formed by the development of competition case law itself. Some time ago 'European law' was a field one could specialize in; now 'European competition law' has become the subject of legal careers. The increasing complexity of competition case law increases the need for specialists. These specialists and their organizations - scholars in universities, practising lawyers in law firms - are important members of this community. In addition, it includes the officials of the national competition authorities, more general (especially international) lawyers' offices, judges, business consultants and policy-makers.

This community has functioned as a channel of information exchange, learning, imitation, and for the explicit transfer of legal concepts and arguments, thus contributing to convergence. There is a certain paradox here: the community, itself created by the complexity of the multi-level legal system, is an instrument for convergence which is supposed to reduce the complexity of this multi-level legal system.

This expert community is a typical example of an 'epistemic community'. The latter has been defined as a 'network of professionals with recognized expertise and competence in a particular domain and an authoritative claim to policy-relevant knowledge within that domain or issue-area' (Haas 1992: 3). This claim to policy-relevant knowledge in a particular domain gives the experts access to the political arena, is their primary power source, and distinguishes them from other groups involved in policy formulation. They share a common worldview (episteme), which has both cognitive and normative dimensions. It is made up of

(1) a shared set of normative and principled beliefs, which provide a valuebased rationale for the social action of community members; (2) shared causal beliefs, derived from their analysis of central problems in their domain and which elucidate the linkages between policy actions and desired out- 
comes; (3) a consensual knowledge base, based on shared notions of validity - that is inter-subjective, internally defined criteria for weighing and validating knowledge in the domain of their expertise (or even a shared faith in a specific method for generating truth); and (4) a common policy enterprise that is a common set of practices associated with a set of problems to which their professional competence is directed.

(Haas 1992: 3; authors' italics)

The combination of these four characteristics distinguishes epistemic communities from other groups, such as interest groups (no shared causal beliefs, no shared knowledge base) or professions (no shared principled beliefs, no shared interests).

Their professional training and socialization, and criteria for excellence, prestige and reputation, set the members apart from other social groups and serve as barriers to entry into the community. They help policy-makers in defining their interests, analysing problems and cause-and-effect relationships, propose specific policies, and identify issues for negotiation.

The communities act as channels for the generation, circulation, and diffusion of ideas and information, as well as jobs and career opportunities, from community to government, and from country to country, as the communities usually cross national boundaries. Peer pressure within the transnational community can be a source for mutual adaptation: your (or our) system is not in line with our basic beliefs.

The transnational community of competition law experts has these characteristics:

- shared normative and cognitive principles, e.g. the importance of legality and precedence, in the interests of legal equality and legal certainty. Legality also implies the supremacy of EU law.

- causal beliefs and a consensual knowledge base: the rules of legal factfinding, of interpretation, hermeneutics, precision and formality, a shared language, shared concepts in which societal problems are redefined as legal problems, etc.

- a common policy enterprise: they are all committed to regulating markets, fair play, and perhaps even to European integration.

- a common legal training, which socializes the members in a common language of discourse, shared norms and values, problem formulations and methods for reaching solutions, giving the community coherence.

However, the community of lawyers (here meaning legally trained experts) is a special epistemic community. It differs from the scientific or engineering communities, to whom the concept was originally applied.

1 Unlike natural science or engineering, the discipline and profession of law is innately normative. Hence the community has stricter norms regarding 
what is acceptable and what is not. The norms are, however, in particular procedural norms, as to the legality of rules and proofs, how to get at the truth, what is a legal fact, etc., and the importance of precedent in restricting future choices, thus creating a kind of path dependency.

2 They deal with social and political issues rather than natural science. Hence consistency in their reasoning is not only needed for scientific reasons, but also for social ones.

3 They are strongly institutionalized politically and at the forefront of policymaking. Lawyers are not only policy advisers, as is the case for most epistemic communities investigated in the special issue of International Organization (Haas 1992); they are the policy- and rule-makers themselves. They make, or at least draft, primary and secondary legislation, formulate Decisions that make up case law, or formulate comments on cases.

4 Their epistemic community is, unlike others, hierarchically structured, along the lines of the legal institutions. More than in other epistemic communities it matters not only what some member says, but who says it. The top of the hierarchy is formed by lawyers in the high courts and in university law departments in each country; and at the European level, in the ECJ and the CEC. Because legal institutions are relatively independent from other political and societal ones, the leaders have a certain authority and independence, which some - notably in the ECJ - can and do use to be a catalyst, a source of ideas, precedents and decisions, which are sometimes unwelcome to politicians (Alter and Meunier-Aitsahalia 1994).

5 Because they play such an active role in society, members of the community, notably commercial lawyers, not only generate interpretations and ideas, but also have interests, which are derived from their institutional task: to defend their clients' interests. This may have consequences for the development of the law and the profession. Thus, lawyers' commercial interests have been a major force driving the litigation craze in American tort law (Zywicki 2001).

Traditionally, the legal profession has been segmented along national borders, as law was valid only within specific national boundaries, creating a diversity of national legal epistemic communities. These had their - often centuries old - institutions, language, legal concepts, precedents, customs, rituals, career paths, etc. However, the internationalization of law, especially in the EU, has been followed by an internationalization of the epistemic community of lawyers. This process has been fostered by the emergence of international organizations, not only international courts, but also international law firms, and the internationalization of university law departments. Internationalization has been fostered by the interests of community members. Commercial lawyers have, in their interest in defending clients, searched for 
arguments, including other jurisdictions and legal systems, such as those across national borders. Drafters of legislation and case decisions may look across borders for definitions, operationalizations and interpretations, especially in complicated and technical issues, thus also contributing to the diffusion of ideas and the internationalization of law.

In competition policy, the internationalization of epistemic communities has been fostered by various procedures which link national and EU levels. Thus, national officials and courts have been involved in the application of EU anti-trust rules by means of participating in advisory committees; and EU law has granted national authorities the jurisdiction to apply EU competition law (except art. 81(3) and merger control), that is, until the CEC itself begins a procedure in a specific case. National authorities have voluntarily taken this opportunity. The German Bundeskartellamt began to apply EU rules instead of national law in the exempted sectors. German courts began to emphasize the relevance of EU law also for the application of national law. In actual enforcement, Commission inspectors and national competition regulators met and co-operated in the context of investigations, carried out by the Commission.

\subsubsection{Functions of this community}

These contacts - facilitated by the Internet - have led competition officials to develop a greater interest in the solutions of their counterparts in other member states and in the cases and solutions of EU officials. Thus, the formation and coherence of the international epistemic community of legally trained officials has to some extent become self-reinforcing - and that may lead to convergence itself also becoming self-reinforcing.

The community allows for European ideas to infiltrate the national level, but it also facilitates actors at the EU level to draw lessons from application by national actors. As contacts increased, it became natural to look for solutions to problems in EU law or in the law of other member states, rather than in that of other countries, like Japan: first, because national actors had already learned about it through 'learning by doing'; second, because such ideas would be compatible with the more general interest of policy-makers in harmonization with EU law.

Lawyers and policy-makers found solutions for certain technical problems elsewhere. In all three countries, the interpretation of certain terms and also certain situations has repeatedly been 'borrowed' from EU case law; especially ideas concerning technical problems, such as the definition of the relevant market or the proof of concerted behaviour. Although each case has its own specific merits, certain problems arise time and again. If a competition authority in one country has to define the relevant market for car spare parts, its analysis can often be a useful basis for the same analysis in another country. 
Adopting solutions from other countries saves time and resources. This was especially important in Austria, as it has few personnel resources. The introduction of merger control in Austrian law was not triggered by EU law, but when the legislator decided on its introduction, inspiration was sought both in the EU and Germany. The same held for the latest amendment of 1999, which included selling below the purchase price as an example of abuse of dominant position.

This borrowing from over the border did not amount to mere copying. Austrian policy-makers took inspiration, and sometimes concrete formulations, from abroad, notably Germany and the EU, but combined them into something different. The policy transfer from the two foreign examples was organized around the core of existing national policy, especially by adopting definitions, but at the same time linking them to more lenient national criteria and different legal consequences, more befitting its corporatist tradition.

Ideas are especially important in complex policies with uncertainty concerning eventual outcomes. Since the effects of competition policy are difficult to measure, ideas matter. There is no direct link between ideas on the form and desirability of competition, on the one hand, and of competition policy, on the other. There are various economic schools of thought, with different concepts of competition and different ideas concerning competition policy. In this 'limbo', EU competition policy had the function of 'field experiment'. It allowed for policy learning concerning the effects of specific competition policies. The Dutch and Austrians traditionally believed that strict competition policy would lead to cut-throat competition and decrease competitiveness. For them, EU policy was their first direct contact with a prohibition system, with merger control, and, for Austria, with rules on abusing a dominant position. EU experience taught that a prohibition system does not lead to a breakdown of the economy. This has helped to remove some of the worst fears of its opponents, or to diminish the legitimacy of their arguments.

The community has been not only a channel for the exchange and diffusion of ideas, information, definitions and arguments, but also a medium for the development of some consensus on certain principles, catalysed by the works of legal scholars and repeated written comments by the CEC. But consensus is not complete, not even now. Often interests in protecting one's own turf get in the way. The German Bundeskartellamt is still uncertain that it has no jurisdiction to prohibit agreements that come under an EC block exemption. Nevertheless, no open conflicts have occurred to date.

\section{CONCLUSION}

Convergence between national competition policies has taken place, and we have tried to measure it in this paper. It cannot be explained by either positive or negative integration. A subtler force has been at work. We have investigated the role of various actors in this process, whose importance is emphasized in 
different theoretical approaches: institutionalism, neo-functionalism and the epistemic community approach.

Indications for each force have been found. There has been some 'top-down' pressure from the CEC and the ECJ, but it was subtle pressure, an indirect criticism of national competition laws. The medium was European case law, the sum of the Decisions of the Commission and the Court. This did not have formal authority in the different sphere of national competition law; there was no legal compulsion to follow it. However, by doubling the legal system, and generating uncertainty, it increased the costs of compliance for business, and hence its potential interests in harmonization.

However, most important for the reception of the subtle top-down pressures has been the development of an epistemic community of legally trained officials around the growing body of competition case law. This not only provided a channel for the exchange of information, ideas, solutions and arguments between the systems and levels of law; its members themselves were active producers of European and national law, and hence could contribute directly to their convergence. For this community, EU case law provided an important model, an experiment and a source of norms in the development of national competition policies.

The CEC has been fully aware of this subtle form of harmonization. It referred explicitly to it in its twenty-fifth competition report (1996: 95), where it stated that convergence of national competition law is important, but that this

is done not through any formal act of harmonization but through a continuation of, and improvement in, communication and co-operation between Community and national enforcement officials ... This process of 'soft harmonization' is a natural consequence of the integration process, which creates pressure for a level playing field throughout the Community.

It does not appear to have been a conscious strategic choice of the Commission, made some time in the early years of European integration. But if it had been, it would not have been injudicious. The strategy may perhaps have been slow, but in the long run not ineffective; and it is certainly low key, which avoids strong resistance by gradually building consensus - quite different from harmonization strategies in other policy fields.

Address for correspondence: Frans van Waarden, Department of Economics and Public Policy, Faculty of Social Sciences, Utrecht University, Postbox 80140, 3508 TC Utrecht, The Netherlands. Tel: +31 30253 4820. email: F.vanwaarden@fss.uu.nl

\section{NOTE}

1 Currently, reforms are under way which will abolish this advisory body. A competition authority, forming part of the Ministry of Economic Affairs, will 
have powers of investigation and initiation of proceedings. However, the social partners will nominate some of the members of the advisory commission of this competition authority. Additionally, a cartel prosecutor, under the Justice Ministry, will be installed. The creation of these two new authorities at both Ministries typifies their long-standing mutual rivalry. Final judgment will still be made by a specialized court.

\section{REFERENCES}

Alter, Karen J. and Meunier-Aitsahalia, Sophie (1994) 'Judicial politics in the European Community', Comparative Political Studies 26(4): 535-61.

Drahos, Michaela (2001) Convergence of Competition Laws and Policies in the European Community, Deventer: Kluwer.

Dumez, Herve and Jeunemaitre, Alain (1996) 'The convergence of competition policies in Europe: internal dynamics and external imposition', in Suzanne Berger and Ronald Dore (eds), National Diversity and Global Capitalism, Ithaca and London: Cornell University Press, pp. 216-38.

European Commission (1996) XXVth Report on Competition Policy, 1995, Luxembourg: Office for Official Publications.

Gerber, David J. (1998) Law and Competition in Twentieth Century Europe: Protecting Prometheus, Oxford: Clarendon Press.

Haas, Ernest B. (1964) Beyond the Nation-State: Functionalism and International Organization, Stanford: Stanford University Press.

Haas, Peter M. (1992) 'Introduction: Epistemic communities and international policy coordination', International Organization 46(1): 1-35.

Héritier, Adrienne (1995) " "Leaders" and "laggards" in European clean air policy', in Brigitte Unger and Frans van Waarden (eds), Convergence or Diversity: Internationalization and Economic Policy Response, Aldershot: Avebury, pp. 278-306.

Héritier, Adrienne and Knill, Christoph (2000) 'Differential responses to European policies: a comparison', in Adrienne Héritier et al. (eds), Differential Europe. The European Union Impact on National Policymaking, Lanham: Rowman \& Littlefield.

Laudati, Laraine L. (1998) 'Impact of Community competition policy on member state competition law', in Stephen Martin (ed.), Competition Policies in Europe, Amsterdam: Elsevier, pp. 381-410.

Lindberg, Leon N. and Scheingold, Stuart A. (eds) (1971) Regional Integration: Theory and Research, Cambridge: Cambridge University Press.

Scharpf, Fritz W. (1996) 'Negative and positive integration in the political economy of European welfare states, in Fritz Scharpf, Gary Marks, Philippe Schmitter and Wolfgang Streeck (eds), Governance in the European Union, London: Sage.

Van der Woude, M. and Jones, C. (1999) EC Competition Law Handbook, 1999/2000 edn, London: Sweet and Maxwell.

Zywicki, Todd. J. (2001) The Political Economy of Tort Law and Tort Reform, www.gmu.edu/departments/economics/pboettke/zywicki.pdf 